\title{
FAKTOR DETERMINAN NASABAH DALAM PEMILIHAN BANK SYARIAH DI ACEH TENGAH
}

\author{
Inayatillah,MA.Ek \\ Program Studi D-III Perbankan Syariah Fakultas Ekonomi dan Bisnis Islam Ar-raniry Banda \\ Aceh, Indonesia. \\ Email: inayatillah82@gmail.com/inayatillah.djakfar@ar-raniry.ac,id
}

\begin{abstract}
ABSTRAK
Perkembangan dunia perbankan syariah di Indonesia saat ini tidak lepas dari peran utama para nasabah yang memberikan kepercayaan terhadap pihak perbankan untuk mengelola asset keuangannya. Beberapa penelitian terdahulu menyebutkan bahwa banyak kelompok nasabah yang memutuskan pilihannya untuk menjadi nasabah di perbankan syariah karena faktor religiusitasnya, selain itu juga ada yang memilih perbankan syariah dengan faktor rasionalitas ekonomi. Tujuan yang ingin dicapai dalam penelitian ini adalah untuk mengetahui faktor determinan nasabah dalam pemilihan bank syariah di aceh khususnya di kabupaten Aceh Tengah. Alat analisis yang digunakan adalah analisis regresi linier berganda, dengan jumlah sampel 50 nasabah. Diperoleh hasil $y=-5,157+0,167 \times 1+0,409 \times 2$. Berdasarkan uji $f$ yang sudah dilakukan maka dapat diketahui bahwa variabel religiusitas dan rasionalitas ekonomi secara bersama-sama berpengaruh terhadap pilihan nasabah pada bank syariah di kabupaten aceh tengah. Berdasarkan uji t yang sudah dilakukan dapat diketahui bahwa secara partial baik variabel religiusitas maupun variabel rasionalitas ekonomi berpengaruh terhadap pilihan nasabah pada bank syariah di kabupaten Aceh Tengah
\end{abstract}

Key word: Bank Syariah, nasabah, pilihan, rasionalitas ekonomi, religiusitas

\begin{abstract}
The development of the world of Islamic banking in Indonesia is currently inseparable from the main role of customers who provide trust in the banking sector to manage their financial assets. Several previous studies stated that many groups of customers decided their choice to become customers in Islamic banking because of their religiosity, while others chose Islamic banking with a factor of economic rationality. The aim to be achieved in this study is to find out the determinant factors of customers in the choice of Islamic banks in Aceh, especially in the district of Central Aceh. The analytical tool used is multiple linear regression analysis, with a sample of 50 customers. The results obtained are $y=-5.157+0.167 \times 1+0.409 \times 2$. Based on the $f$ test that has been done, it can be seen that the variables of religiosity and economic rationality together influence the choice of customers in Islamic banks in central Aceh district. Based on the t-test that has been done, it can be seen that both the religiosity variable and the economic rationality variable partially influence the choice of customers in Islamic banks in Central Aceh district.
\end{abstract}

Key word: Islamic banks, customers, choices, economic rationality, religiosity 


\section{PENDAHULUAN}

Penelitian ini membahas tentang faktor determinan nasabah dalam pilihan bank syariah di Aceh Tengah. Penulis tertarik membahas hal ini karena di Aceh sedang diberlakukannya syariat Islam dalam segala bidang termasuk dalam bidang ekonomi atau muamalah sehingga nantinya akan terjawab apakah masyarakat memilih bank syariah karena alasan agama/religiusitas, atau rasionalitas ekonomi.

Selama ini masyarakat mengenal Lembaga Keuangan Bank merupakan suatu lembaga profit yang tujuan utamanya adalah keuntungan. Untuk menghimpun dana dari masyarakat secara langsung, bank menawarkan berbagai layanan produk dan jasa seperti memberi kredit pinjaman kepada masyarakatyang membutuhkan, jual beli valuta asing/valas, menjual jasa asuransi, jasa giro, jasa cek, menerima penitipan barang berharga, dan lain sebagainya ${ }^{1}$. Masyarakat dalam memanfaatkan jasa perbankan juga melihat dari produk dan layanan apa saja yang menguntungkan bagi mereka.Intinya faktor ekonomi selalu menjadi pilihan utama masyarakat dalam bertransaksi di perbankan.

Beberapa penelitian yang telah dilakukan di dalam maupun di luar negeri mengenai prefensi nasabah bank syariah pada umumnya menemukan bahwa faktor ekonomi lebih dominan bila dibandingkan dengan faktor demografi dan faktor sosial. ${ }^{2}$ Akan tetapi ada juga beberapa penelitian yang menunjukkan bahwa faktor sosial atau agama lebih dominan daripada faktor ekonomi.

http://www.academia.edu/4370515/LEMBAGA_PERBANKAN_INDONESIA

2Direktorat Penelitian dan Pengaturan Perbankan -Bank Indonesia tentang RingkasanPokok-Pokok Hasil Penelitian "Potensi, Pilihan dan PerilakuMasyarakat terhadap Bank Syariah di Pulau Jawa" (Jakarta: Bank Indonesia, 2000), baca juga hasil penelitian Bank Indonesia dan Pusat Penelitian Kajian Pembangunan Lembaga Penelitian Universitas Diponegoro, tentang "Potensi, Pilihan dan PerilakuMasyarakat terhadap Bank Syariah di Pulau Jawa Tengah dan Daerah Istimewa Yogyakarta"(Semarang: Bank Indonesia, 2000) lihat juga hasil penelitian Bank Indonesia danLembaga Penelitian IPB tentang "Potensi, Pilihan dan PerilakuMasyarakat terhadap Bank Syariah di Pulau Jawa Barat" (Bogor: Bank Indonesia, 2000), dan bandingkan pula dengan hasil penelitian Bank Indonesia dan Pusat Pengkajian Bisnis dan Ekonomi Islam Fakultas Ekonomi Universitas Brawijaya tentang "Potensi, Pilihan dan PerilakuMasyarakat terhadap Bank Syariah di Pulau Jawa Timur" (Malang: Bank Indonesia, 2000). 
Pada dasarnya nasabah atau masyarakat menetapkan pilihannya terhadap sesuatu berdasarkan persepsi mereka. Oleh karenanya Walgito dalam bukunya Pengantar Psikologi Umum menjelaskan bahwa persepsi sangat dipengaruhi beberapa faktor antara lain: faktor situasi, kebutuhan dan keinginan, juga keadaan emosi. ${ }^{3}$

Beberapa penelitian terbaru diantaranya yang telah dilakukan dilakukan oleh Faisal Indra Setiawan dan Ananda Sabil Hussein dengan judul Pengaruh Persepsi Religiusitas Terhadap Loyalitas Nasabah Bank Muamalat Kota Cirebon dengan Kepuasan Nasabah Sebagai Variabel Intervening. Variabel persepsi religiusitas dengan indikator bisnis halal, pelarangan riba dan simbol keagamaan menunjukkan pengaruh positif signifikan terhadap loyalitas nasabah dibuktikan dengan nilai Thitung $=3.700>$ Ttabel $=1.66462$ dan nilai signifikansi $0,000<0,05$. 4

Penelitian yang dilakukan oleh Atik Masruroh dengan judul "Analisis Pengaruh Tingkat Religiusitas dan Disposible Income terhadap Minat Menabung Mahasiswa di Perbankan Syariah (Studi Kasus Mahasiswa STAIN Salatiga)" juga menyebutkan bahwa adanya pengaruh signifikan dari disposible income terhadap minat menabung di bank syariah jika dimoderasi dengan variabel religiusitas. ${ }^{5}$

Desy Fatmawati melakukan penelitian tentang "Pengaruh Pendapatan, Religiusitas, Dan Informasi Terhadap Intensi Menabung Di Bank Syariah Pada Kalangan Santri Mahasiswa Pp. Wahid Hasyim Di Sleman" menunjukkan bahwa Hasil probit regression menunjukkan bahwa variabel pendapatan tidak berpengaruh terhadap intensi menabung di bank syariah pada kalangan santri mahasiswa Pondok Pesantren Wahid Hasyim. Sedangkan variabel religiusitas dan informasi masing-masing berpengaruh terhadap intensi menabung di bank syariah pada kalangan santri mahasiswa Pondok Pesantren Wahid Hasyim. Jika dilihat secara simultan, ketiga variabel bebas tersebut secara bersama-sama berpengaruh terhadap intensi menabung di

${ }^{3}$ Kotler dikutip dalam buku Bimo Walgito, Pengantar Psikologi Umum (Yogyakarta: Andi Ofset, 2001), 54.

${ }^{4}$ Faisal Indra Setiawan dan Ananda Sabil Hussein, "Pengaruh Persepsi Religiusitas Terhadap Loyalitas Nasabah Bank Muamalat Kota Cirebon dengan Kepuasan Nasabah Sebagai Variabel Intervening", Jurnal Ilmiah Mahasiswa Fakultas Ekonomi dan Bisnis Universitas Brawijaya, 2016.

${ }^{5}$ Atik Masruroh "Analisis Pengaruh Tingkat Religiusitas dan Disposible Income terhadap Minat Menabung Mahasiswa di Perbankan Syariah (Studi Kasus Mahasiswa STAIN Salatiga)"Skripsi, STAIN Salatiga, 2015. 
bank syariah pada kalangan santri mahasiswa Pondok Pesantren Wahid Hasyim. Kemudian nilai correctly classification yang didapatkan sebesar $67,20 \%$. Hal ini berarti secara umum model dapat menjelaskan seluruh kejadian sebesar $67,20 \% .^{6}$

Nikmah Zahrotun meneliti tentang "Pengaruh dimensi religiusitas masyarakat santri desa Kajen kecamatan Margoyoso kabupaten Pati terhadap minat menabung (studi kasus pada BPRS Artha Mas Abadi)" menunjukkan dimensi religiusitas masyarakat santri Desa Kajen Kecamatan Margoyoso Kab. Pati berpengaruh terhadap minat menabung di BPRS Artha Mas Abadi sebesar $66,0 \%$, dibuktikan dengan uji statistik menunjukkan bahwa variabel independen (religiusitas) terhadap variabel dependen (minat menabung) adalah signifikan. Ini ditunjukkan dengan lebih besarnya t hitung dengan $t$ table $(13,801>1,9845)$. Besarnya pengaruh dinotasikan oleh R2 adalah 660 yang artinya variabel minat menabung dapat dijelaskan oleh variabel dimensi religiusitas $66,0 \%$ dan sisanya 34,0 \% dipengaruhi oleh faktor lain diluar penelitian ini. Persamaan regresi yang diperoleh adalah $Y=-0,635+0,605 X .{ }^{7}$

Alfi Muflikhah Lestari melakukan penelitian tentang "Pengaruh Religiusitas, Produk Bank, Kepercayaan, Pengetahuan, Dan Pelayanan Terhadap Preferensi Menabung Pada Perbankan Syariah (Studi Kasus Pada Mahasiswa Fakultas Ekonomi Dan Bisnis Universitas Brawijaya Malang)", Hasil analisis faktor menunjukan pengaruh religiusitas terhadap preferensi utama menabung pada perbankan syariah adalah kepatuhan agama.Pengaruh produk bank terhadap preferensi utama menabung pada perbankan syariah adalah produk yang inovatif.Pengaruh kepercayaan terhadap preferensi utama menabung pada perbankan syariah adalah kemudahan bertransaksi. Pengaruh pengetahuan terhadap preferensi utama menabung pada perbankan syariah adalah pengetahuan ilmiah. Dan pengaruh pelayanan terhadap preferensi utama menabung pada perbankan syariah adalah penggunaan fasilitas yang mudah. ${ }^{8}$

6 Desy Fatmawati "Pengaruh Pendapatan, Religiusitas, Dan Informasi Terhadap Intensi Menabung Di Bank Syariah Pada Kalangan Santri Mahasiswa Pp. Wahid Hasyim Di Sleman", Skripsi, Yogyakarta: Universitas Negeri Yogyakarta, 2015

7 Nikmah Zahrotun meneliti "Pengaruh dimensi religiusitas masyarakat santri desa Kajen kecamatan Margoyoso kabupaten Pati terhadap minat menabung (studi kasus pada BPRS Artha Mas Abadi)", Skripsi, IAIN Wali Songo, 2013

8 Alfi Muflikhah Lestari “Pengaruh Religiusitas, Produk Bank, Kepercayaan, Pengetahuan, Dan Pelayanan Terhadap Preferensi Menabung Pada Perbankan Syariah (Studi Kasus Pada Mahasiswa Fakultas Ekonomi Dan Bisnis Universitas 
Bisa dikatakan bahwa pilihan konsumen sangat tergantung pada persepsi atau pengetahuan dan perilaku seorang konsumen. Menurut James F. Engel perilaku konsumen didefinisikan sebagai tindakan-tindakan individu yang secara langsung terlibat dalam usaha memperoleh dan menggunakan barang-barang jasa ekonomi termasuk proses pengambilan keputusan yang mendahului dan menentukan tindakan - tindakan tersebut. ${ }^{9}$

S.J. Kraus dalam penelitiannya yang berjudul "Attitudes and prediction of behavior: a meta-analysis of the empirical literature." menunjukkan bahwasikap memiliki pengaruh signifikan pada perilaku. ${ }^{10} \mathrm{Pada}$ dasarnya setiap manusia memiliki perilaku yang berbeda dengan manusia lainnya. Manusia juga memiliki kemampuan untuk berpikir, sehingga dengan berpikir juga dapat mempengaruhi seseorang dalam berprilaku. Demikian juga halnya dalam melakukan interaksi, seseorang dengan memiliki kemampuan berpikir tadi akan memperhitungkan orang lain dan memutuskan bagaimana harus bertingkah laku atau bersikap supaya cocok dengan orang tersebut. ${ }^{11}$ Karena itu, pembentukan sikap pada diri seseorang sangat dipengaruhi banyak faktor, diantaranya; pengalaman pribadi, kebudayaan, orang lain yang dianggap penting (Significant Others), media massa, institusi / lembaga pendidikan dan agama, serta faktor emosional. ${ }^{12}$

Perubahan sosial atau transformasi dalam masyarakat dari masyarakat tradisional atau pramodern kepada masyarakat modern, menyebabkan pola interaksi dan komunikasi juga akan berubah sesuai dengan realitas abad ke21. Sehingga tingkah laku masyarakat sekalipun dalam hal ekonomi digantungkan pada asumsi-asumsi rasionalitas.

Asumsi rasionalitas adalah anggapan bahwa manusia berperilaku secara rasional (masuk akal), dan tidak akan secara sengaja membuat

Brawijaya Malang)" Skripsi, Jurusan Ilmu Ekonomi Fakultas Ekonomi dan Bisnis Universitas Brawijaya, 2015

${ }^{9}$ James F. Engel, Consumer Behavior(Illinois: The Dryden Press, 1968), 8. Dikutip dari buku A. A. Anwar Prabu Mangkunegara, Perilaku Konsumen (Bandung: Refika Aditama, 2002), 3.

10 S.J. Kraus, "Attitudes and prediction of behavior: a meta-analysis of the empirical literature." Personality and Social Psychology Bulletin, Januari 1995, 21, 58-75.

${ }^{11}$ Bernard Raho, SVD, Teori Sosiologi Modern, (Jakarta: Prestasi Pustakaraya, 2007), 108

12Sri Utami Rahayuningsih, "Psikologi Umum 2"

nurul_q.staff.gunadarma.ac.id/Downloads/files/.../bab1-sikap-1.pdf akses 10 November 2010). 
keputusan yang akan menjadikan mereka lebih buruk. ${ }^{13}$ Artinya seseorang dikatakan memiliki dimensi rasional makala bentuk pikiran dan tindakannya logis, terhitung, terukur, teranalisis dengan baik dan melalui penalaran yang tepat. ${ }^{14}$

Adiwarman Karim dalam bukunya Ekonomi Mikro Islami menyebutkan bahwa perilaku rasional mempunyai dua makna, yaitu pertama: metode, "action selected on the basis of reasoned thought rather than out of habit, prejudice, or emotion"(tindakan yang dipilih berdasarkan pikiran yang beralasan, bukan berdasarkan kebiasaan, prasangka atau emosi), dan kedua:makna,"action that actually succeeds in achieving desired goals"(tindakan yang benar-benar dapat mencapai tujuan yang ingin dicapai). 15

Dari uraian di atas, nantinya akan dikaji faktor determinan nasabah dalam pemilihan bank syariah di Kabupaten Aceh tengah. Apakah religiusitas dan rasionalitas ekonomi memberikan dampak terhadap pilihan nasabah pada bank syariah di Aceh Tengah. Sehingga penelitian ini diharapkan mampu membangkitkan kembali kesadaran masyarakat terutama motif mereka dalam bermuamalah diperbankan syariah agar tidak hanya sekedar mendapatkan keuntungan tetapi juga karena ingin menghindari riba.

\section{KERANGKA BERPIKIR DAN PENGEMBANGAN HIPOTESIS}

Pada dasarnya kerangka pemikiran dibuat berdasarkan pertanyaan penelitian (research question), dan merepresentasikan suatu himpunan dari beberapa konsep serta hubungan diantara konsep-konsep tersebut. ${ }^{16}$ Adapun kerangka berpikir dalam penelitian ini sebagai berikut:

Gambar 1. Kerangka Pemikiran

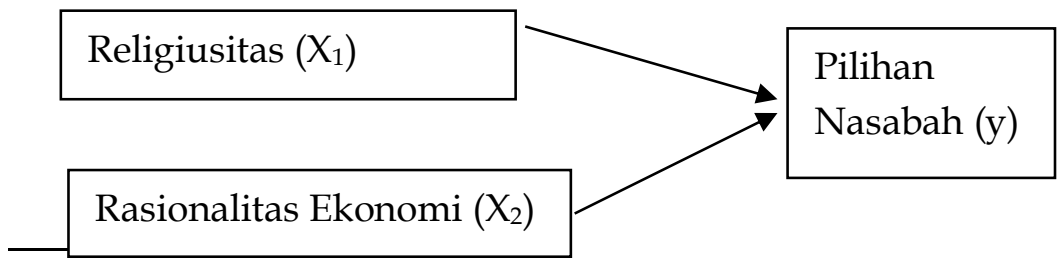

${ }^{13}$ Roger LeRoy Miller, Economics Today $7^{\text {th }}$ (New York: Harper Collins Publishers, 2001), 6, dikutip dalam Adiwarman A. Karim, Ekonomi Mikro Islami (Jakarta: PT. RajaGrafindo Persada, 2007), 51.

${ }^{14}$ Muhammad Muflih, Perilaku Konsumen Dalam Perspektif Ilmu Ekonomi Islam (Jakarta: PT. RajaGrafindo Persada, 2006), 90.

${ }^{15}$ Adiwarman A. Karim, Ekonomi Mikro Islami (Jakarta: PT. RajaGrafindo Persada, 2007), 51.

16 Gregor Polancik, Empirical Research Method Poster (Jakarta, 2009) 
Hipotesis dalam penelitian ini adalah

$\mathrm{H}_{0}=$ religiusitas dan rasionalitas tidak mempunyai pengaruh signifikan terhadap pilihan nasabah pada Bank Syariah di Aceh Tengah.

$\mathrm{H}_{1}=$ religiusitas dan rasionalitas mempunyai pengaruh signifikan terhadap pilihan nasabah pada Bank Syariah di Aceh Tengah.

\section{METODE}

Jenis data yang dikumpulkan dalam penelitian ini berbentuk data kuantitatif yang nantinya akan dianalisis ke dalam bentuk descriptive analysis. Data kuisioner yang berbentuk kuantitatif, proses analisis datanya dibantu dengan menggunakan Statistical Packages for the Social Science (SPSS) versi 16. Penelitian ini menggunakan dua sumber data yaitu: data sekunder yaitu berbagai data yang diperoleh melalui buku, jurnal, penelitian, disertasi, majalah surat kabar. Data Sekunder digunakan untuk memperoleh informasi terkait penelitian terdahulu dan juga terkait dengan perkembangan bank syariah. Kemudian data primer yaitu data yang diperoleh dari nasabah secara langsung dengan menggunakan instrumen kuisioner. Pengumpulan data melalui kuisioner dengan menggunakan pertanyaan tertutup yang diajukan kepada responden.

Populasi dalam penelitian ini adalah nasabah pada Bank Syariah di Kabupaten Aceh Tengah tahun 2018. Sedangkan sampel yang di ambil sebanyak 50 responden ${ }^{17}$ yang terdiri dari nasabah Bank Syariah Mandiri dan

\footnotetext{
${ }^{17}$ Roscoe dalam buku Research Method for Business (1982: 253) memberikan saransaran tentang ukuran sampel untuk penelitian seperti berikut ini:1. Ukuran sampel yang layak dalam penelitian adalah antara 30 sampai dengan 500. 2. Bila sampel dibagi dalam kategori (misalnya: pria-wanita, pegawai negeri-swasta dan lainnya) maka jumlah anggota sampel setiap kategori minimal 30. 3. Bila dalam penelitian akan melakukan analisis dengan multivariate (korelasi atau regresi ganda misalnya), maka jumlah anggota sampel minima 10 kali dari jumlah variable yang diteliti. Misalnya vaiabel penelitiannya ada 5 (independen + dependen), maka jumlah anggota sampel $=10$ X $5=50.4$. Untuk penelitian eksperimen yang sederhana, yang menggunakan kelompok eksperimen dan kelompok control, maka jumlah anggota sampel masing-masing kelompok antara 20 sampai dengan 20. Lihat Sugiyono, Statistika untuk Penelitian, 74. Bandingkan dengan Suharsimin Arikunto, Prosedur Penelitian; Suatu Pendekatan Praktek (Jakarta: PT. Rineka Cipta, 1998), 121. Arikunto menyebutkan bahwa kebanyakan peneliti beranggapan bahwa semakin banyak sampel, atau semakin banyak persentase sampel dari populasi, hasil penelitian akan semakin baik. Anggapan ini benar, tetapi tidak selalu demikian. Hal ini tergantung dari sifat-sifat atau cirriciri yang terkandung oleh subjek penelitian dalam populasi. Selanjutnya sifat-sifat atau ciri-ciri tersebut bertalian erat dengan homogenitas subjek dalam populasi.
} 
Bank Aceh Syariah. Pengambilan sampel dalam penelitian ini menggunakan purposive sampling18.

Berdasarkan obyek penelitian dan metode penelitian yang digunakan, maka dibawah ini diungkapkan operasionalisasi variabel penelitian adalah sebagai berikut:

a. Variabel bebas atau X (Indepandent Variabel).

Yaitu variabel yang dapat mempengaruhi variabel pilihan nasabah (dependen variabel atau terikat). Variabel bebas yang dimaksud dalam penelitian ini adalah religiusitas dan rasionalitas ekonomi.

b. Variabel terikat atau Y (Depandent Variabel).

Yaitu variabel yang dapat dipengaruhi oleh variabel religiusitas dan rasionalitas ekonomi (Independet variabel atau bebas). Variabel terikat yang dimaksud dalam penelitian ini adalah pilihan nasabah.

Adapun operasional variabel, dan skala pengukuran yang digunakan dalam penelitian ini dapat dilihat dalam tabel di bawah ini:

Tabel. 3.1

Definisi Operasional Variabel

\begin{tabular}{|c|c|c|}
\hline Variabel & Definisi Operasional & Pengukuran \\
\hline $\begin{array}{c}\text { X1 } \\
\text { Religiusitas }\end{array}$ & $\begin{array}{l}\text { Terdapat lima dimensi dalam religiusitas: } \\
\text { (1) dimensi keyakinan atau Ideologis, (2) } \\
\text { praktik agama atau ritualistic (3) } \\
\text { pengalaman atau eksperiensial, (3) } \\
\text { pengalaman atau eksperiensial, (4) } \\
\text { pengetahuan agama atau intelektual, (5) } \\
\text { Konsekuensi }\end{array}$ & $\begin{array}{l}\text { Skala } \\
\text { Interval } \\
1-5\end{array}$ \\
\hline $\begin{array}{c}\text { X2 } \\
\text { Rasionalitas } \\
\text { Ekonomi }\end{array}$ & $\begin{array}{l}\text { Dimensi rasional mencakup bentuk } \\
\text { pikiran dan tindakan yang logis, } \\
\text { terhitung, terukur, teranalisis dengan } \\
\text { baik dan melalui penalaran yang tepat }\end{array}$ & $\begin{array}{l}\text { Skala } \\
\text { Interval } \\
1-5\end{array}$ \\
\hline $\begin{array}{c}\text { Y } \\
\text { Pilihan }\end{array}$ & $\begin{array}{l}\text { Pilihan konsumen sangat berhubungan } \\
\text { erat sikap individu terhadap sesuatu }\end{array}$ & $\begin{array}{l}\text { Skala } \\
\text { Interval }\end{array}$ \\
\hline
\end{tabular}

${ }^{18}$ Purposive sampling adalah teknik penentuan sampel dengan pertimbangan tertentu misalnya penelitian tentang kondisi politik disuatu daerah, maka sampel sumber datanya adalah orang yang ahli politik. Sampel ini lebih cocok digunakan untuk penelitian kualitatif, atau penelitian-penelitian yang tidak melakukan generalisasi. Sugiyono, Statistika untuk Penelitian (Bandung: CV. Alfabeta, 2009), 68. 


\begin{tabular}{|l|l|l|}
\hline Nasabah & $\begin{array}{l}\text { objek dalam menetapkan pilihan karena } \\
\text { suka atau berkeinginan lebih dari yang } \\
\text { lain. }\end{array}$ & \\
\hline
\end{tabular}

Untuk menganalisis data yang telah terkumpul dari hasil penelitian ini, maka penulis menggunakan analisis statistik dengan langkah-langkah sebagai berikut:

\section{Uji Validitas dan Reliabilitas}

Uji validitas dilakukan untuk mengetahui apakah suatu instrumen alat ukur telah menjalankan fungsi ukurannya. Suatu skala pengukuran disebut valid bila ia melakukan apa yang seharusnya dilakukan dan mengukur apa yang seharusnya diukur. Untuk mengetahui apakah masing-masing variabel dalam penelitian ini telah benar-benar mengukur apa yang ingin di ukur, maka metode yang digunakan adalah korelasi Product Moment Pearson. ${ }^{19}$ Pengambilan keputusannya bahwa setiap indikator valid apabila nilai $r$ hitung lebih besar atau sama dengan $r$ tabel. Untuk menentukan nilai $r$ hitung,dibantu dengan program SPSS yang dinyatakan dengan nilai Corrected Item Total Correlation.

Uji reliabilitas adalah uji kepercayaan terhadap instrumen. Suatu instrumen dapat memiliki tingkat kepercayaan yang tinggi jika hasil dari pengujian instrumen tersebut menunjukkan hasil yang tepat. Uji reliabilitas dilakukan untuk mengetahui tingkat kestabilan suatu alat ukur, jika digunakan dalam beberapa kali pengukuran terhadap kelompok subyek yang sama diperoleh hasil yang relatif sama, maka hasil pengukuran dianggap sudah dapat dipercaya. Untuk mengetahui reliabilitas hasil ukur dapat dilakukan dengan melihat nilai cronbach alpha. Dimana pada pengujian reliabilitas ini menggunakan bantuan komputer program SPSS.

\section{Analisis Data}

Untuk menganalisa secara kuantitatif digunakan alat sebagai berikut:

a. Uji Asumsi Klasik

Cara yang digunakan untuk menguji penyimpangan asumsi klasik salah satunya dengan uji normalitas. Uji normalitas dilakukan untuk

19 Toni Wijaya, Analisi Data Penelitian Menggunakan SPSS (Yogyakarta : Penerbit Universitas Atma Jaya, 2009), hlm 113 
melihat apakah dalam model regresi variabel terikat dan variabel bebas keduanya memiliki distribusi normal atau tidak. Model regresi yang baik adalah yang berdistribusi normal. Kriteria berdistribusi normal apabila tampilan grafiknya menunjukkan pola penyebaran disekitar garis diagonal dan mengikuti arah garis diagonal. ${ }^{20}$

b. Analisis Statistik Deskriptif (Descriptive Statistic)

Analisis ini digunakan untuk menggambarkan dan menjelaskan secara lebih detail masing-masing variabel dalam penelitian ini. Beberapa teknik analisis statistik deskriptif gunakan antara lain :

1) Mode/Modus yaitu data atau angka yang sering muncul yang digunakan untuk mengambil keputusan tentang mayoritas dari kecenderungan data.

2) Standard Deviasi bertujuan untuk mengetahui jarak penyebaran nilai di sekitar mean.

3) Min dan Max, dimana min adalah nilai minimal dari data, mak merupakan nilai maksimal.

4) View Chart and Table, dimana chart digunakan untuk menjelasan data-data dengan menggunakan grafik atau prosentase. Sedangkan tabel digunakan untuk lebih sistematis dan juga untuk memudahkan pembaca.

c. Analisis Regresi Berganda

Analisis regresi linear sederhana digunakan untuk mengetahui seberapa besar pengaruh religiusitas dan rasionalitas ekonomi $(X)$, terhadap Pilihan nasabah $(\mathrm{Y})$. Persamaan regresi linear sederhana dicari dengan rumus:

$Y=a+b 1 X 1+b 2 X 2+b 3 X 3$ bnXn

Dimana :

$$
\begin{array}{cl}
\mathrm{Y} & =\text { Pilihan Nasabah } \\
\mathrm{a} & =\text { Nilai Konstanta } \\
\mathrm{b} & =\text { Koefisien Regresi } \\
\mathrm{X} 1 & =\text { religiusitas } \\
\mathrm{X} 2 & =\text { rasionalitas ekonomi }
\end{array}
$$

d. Uji Hipotesis

20 Toni Wijaya, Analisis Data Penelitian Menggunakan SPSS, Yogyakarta : Penerbit Universitas Atma Jaya, 2009, hlm 129 
Untuk menguji hipotesis digunakan uji $\mathrm{F}$, yaitu uji yang dilakukan untuk mengetahui pengaruh variabel bebas (independent) terhadap variabel tidak bebas (dependent). Adapun langkah-langkahnya yaitu:

$\mathrm{Ho}=$ hipotesis nihil dan $\mathrm{H} \square=$ hipotesis alternatif.

Menentukan rumusan :

Ho: $\rho=0$ : tidak ada pengaruh variabel $X$ terhadap variabel $Y$.

$\mathrm{H} \square: \rho \neq 0$ : ada pengaruh variabel $\mathrm{X}$ terhadap variabel $\mathrm{Y}$.

Menentukan level signifikan $\alpha=5 \%$.

Pengujian hipotesis, apabila nilai hitung $\mathrm{F}$ lebih besar atau sama dengan $(\geq)$ nilai tabel $\mathrm{F}$, maka Ho ditolak. ${ }^{21}$

\section{HASIL DAN PEMBAHASAN}

\section{Uji Validitas da Reliabilitas}

Berdasarkan Tabel 4.1 ditemukan bahwa ada satu pertanyaan yang tidak valid. Hal ini disebabkan mereka memilih menjadi nasabah bank syariah bukan karena ingin mendapatkan bonus/undian. Akan tetapi sebagian besar item pertanyaan memiliki status valid, karena nilai $r_{\text {hitung }}$ (Corrected Item-Total Correlation) $>r_{\text {tabel }}$ sebesar 0,235.

Untuk menguji reliabilitas, data dianalisis menggunakan SPSS versi 16.0 dengan mengunakan model "Cronbach Alpha". Model ini merupakan ujian yang paling popular dan sering dilakukan, karena dapat mengukur kepercayaan data dikotomi dan polikotomi. Berbeda dengan model lain seperti Kuder-Richardson yang berpetokan kepada data dikotomi saja. ${ }^{22}$

Pada dasarnya, nilai reliabilitas alfa Cronbach bermula dari 0.00 hingga 1.00.Nilai alfa yang sering dijadikan sebagai batasan minimal adalah 0.60 (Uma Sekaran, 1992)23, untuk penelitian sains social nilai alfa adalah 0.65 (J. H. Mc Millan \&S. Schumacher, 2006) ${ }^{24}$ dan 0.70 (D. Muijs,

${ }^{21}$ Sambas Ali Muhidin dan Maman Abdurrahman, Analisis Korelasi, Regresi, dan Jalur dalam Penelitian (Bandung: CV. Pustaka Setia, Cetakan Pertama, 2009), hlm 195.

${ }^{22}$ John W. Creswell, Research Design: Qualitative, Quantitative, and Mixed Methods Approach , 2rd edition (London: Sage Publications, 2003), 131. J. H. Mc Millan \&S. Schumacher, Research in Education: Evidence-Based Inquiry (New York: Pearson Education, Inc, 2006), 155.

${ }^{23}$ Uma Sekaran, Research Method for Business: A Skill Building Approach,

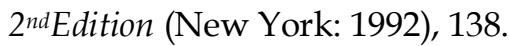

${ }^{24} \mathrm{~J}$. H. Mc Millan \&S. Schumacher, Research in Education: Evidence-Based 
2004)25.Meskipun demikian nilai alfa 0.70 lebih sesuai bagi kajian yang mengukur ciri-ciri kepribadian, sikap dan pandangan. ${ }^{26}$

Hasil analisis data yang dilakukan dalam penelitian ini menunjukkan nilai alfa Cronbach yang didapatkan 0.936. Karena tujuan kajian ini adalah untuk mengukur sikap, maka nilai reliabilitas yang didapat sudah tepat.

\section{Uji Pengaruh Religiusitas dan Rasionalitas Terhadap Pilihan Nasabah Bank Syariah}

\section{a. Uji Asumsi Klasik}

Model regresi linier berganda dapat dikatakan sebagai model yang baik jika model tersebut memenuhi beberapa asumsi yang disebut dengan asumsi klasik. Salah satu uji asumsi yang akan dilakukan yaitu uji normalitas. Uji normalitas bertujuan untuk mengetahui apakah dalam model regresi, variabel penggangu atau residual memiliki distribusi normal. Hasil uji normalitas menyebutkan bahwa residual memiliki distribusi yang normal (tidak melenceng ke kiri maupun ke kanan). Sedangkan dari grafik normal probability plot terlihat titik-titik menyebar di sekitar garis diagonal dan mengikuti arah garis diagonal. Berdasarkan hasil analisis grafik dapat disimpulkan bahwa model regresi telah memenuhi asumsi normalitas.

\section{b. Analisis Regresi Linier Berganda}

Pada penelitian ini, untuk melakukan analisis regresi linier berganda maka peneliti menggunakan bantuan software SPSS 16 untuk menguji faktor determinan nasabah dalam pemilihan bank syariah di Aceh Tengah. Dari hasil perhitungan diperoleh persamaan regresi sebagai berikut:

Inquiry, 153.

${ }^{25} \mathrm{D}$. Muijs,Doing Quantitative Research in Educational with SPSS (London: Sage Publications, 2004), 131.

${ }^{26}$ T. K. Crowl, Fundamentals of Educational Research, $2^{\text {nd }}$ Edition (New York: McGraw - Hill, 1996), 127.J. H. Mc Millan \&S. Schumacher, Research in Education: Evidence-Based Inquiry (New York: Pearson Education, Inc, 2006),163. 
Tabel 4.1

Hasil Perhitungan Regresi

Coefficients ${ }^{\mathrm{a}}$

\begin{tabular}{|l|l|l|l|l|l|}
\hline \multirow{2}{*}{ Model } & \multicolumn{2}{|l|}{$\begin{array}{l}\text { Unstandardized } \\
\text { Coefficients }\end{array}$} & \multicolumn{2}{|l|}{$\begin{array}{l}\text { Standardized } \\
\text { Coefficients }\end{array}$} & \\
\cline { 2 - 4 } & $\mathrm{B}$ & Std. Error & Beta & $\mathrm{t}$ & Sig. \\
\hline 1 (Constant) & -5.157 & 3.528 & & -1.462 & .150 \\
X1 & .167 & .044 & .459 & 3.797 & .000 \\
X2 & .409 & .140 & .352 & 2.917 & .005 \\
\hline
\end{tabular}

a. Dependent Variable:

Persamaan regresi dari hasil analisis di atas adalah:

$\hat{Y}=-1,157+0,167 X_{1}+0,409 X_{2}$

Adapun hasil model regresi linier berganda di atas dapat dijelaskan sebagai berikut:

a. Konstanta $(\alpha)$

Nilai konstanta (a) adalah sebesar -1,157 artinya jika variabel bebas yaitu religiusitas dan rasionalitas ekonomi $=0$, maka nilai variabel terikat yaitu pilihan nasabah akan bernilai sebesar -1,157. Dengan kata lain apabila religiusitas dan rasionalitas ekonomi tidak memberikan pengaruh maka cumulative abnormal return akan bernilai sebesar -1,157.

b. Koefisien regresi $(\beta \mathrm{i})$

Nilai koefisien regresi variable religiusitas adalah sebesar 0,167, artinya jika religiusitas berubah satu satuan, maka rasionalitas ekonomi akan berubah akan berubah sebesar 0,167. Tanda positif pada nilai koefisien regresi tersebut menandakan hubungan yang searah antara religiusitas dan rasionalitas ekonomi, artinya apabila religiusitas meningkat, maka pilihan nasabah juga semakin meningkat. Nilai koefiisen regresi variable indeks rasionalitas ekonomi adalah sebesar 0,409 artinya jika variabel rasionalitas ekonomi berubah satu satuan, maka pilihan nasabah akan berubah sebesar 0,409. Tanda positif pada nilai koefisien regresi tersebut menandakan hubungan yang searah antara religiusitas dan rasionalitas ekonomi, artinya apabila rasionalitas ekonomi meningkat, maka pilihan nasabah juga akan semakin meningkat. 


\section{c. Pengujian Hipotesis Pengaruh Variabel Bebas Secara Bersama- sama Terhadap Variabel Terikat (Uji F).}

Pengujian ini dilakukan untuk mengetahui apakah variabelvariabel bebas secara bersama-sama (simultan) berpengaruh signifikan terhadap variabel terikat. Untuk melakukan pengujian tersebut maka sebelumnya dilakukan pembuktian hipotesis. Hipotesis yang digunakan adalah sebagai berikut :

$\mathrm{H}_{0}=$ religiusitas dan rasionalitas tidak mempunyai pengaruh signifikan terhadap pilihan nasabah pada Bank Syariah di Aceh Tengah.

$\mathrm{H}_{1}=$ religiusitas dan rasionalitas mempunyai pengaruh signifikan terhadap pilihan nasabah pada Bank Syariah di Aceh Tengah.

Dari perhitungan Regresi dengan bantuan aplikasi SPSS 16, maka didapatkan hasil sebagai berikut:

Tabel 4.2

Hasil Perhitungan Regresi

ANOVAb

\begin{tabular}{|l|l|l|l|l|l|}
\hline Model & $\begin{array}{l}\text { Sum of } \\
\text { Squares }\end{array}$ & df & $\begin{array}{l}\text { Mean } \\
\text { Square }\end{array}$ & F & Sig. \\
\hline 1 Regression & 281.189 & 2 & 140.595 & 23.934 & $.000 a$ \\
Residual & 276.091 & 47 & 5.874 & & \\
Total & 557.280 & 49 & & & \\
\hline
\end{tabular}

a. Predictors: (Constant), X2, X1

b. Dependent Variable: $Y$

Berdasarkan hasil uji $\mathrm{F}$ pada tabel di atas diketahui bahwa tingkat signifikansi yang diperoleh adalah 0,000 atau $0 \%$ lebih kecil dari $5 \%$, maka $\mathrm{H}_{0}$ ditolak dan $\mathrm{H}_{1}$ diterima. Dengan demikian dapat disimpulkan bahwa variabel religiusitas dan rasionalitas ekonomi adalah berpengaruh signifikan terhadap pilihan nasabah pada bank syariah di Aceh Tengah 


\section{d. Pengujian Hipotesis Pengaruh Variabel Bebas Secara Parsial Terhadap Variabel Terikat (uji t)}

Pengujian ini digunakan untuk memeriksa apakah variabel bebas secara individu berpengaruh signifikan terhadap variabel terikat. Untuk melakukan pengujian tersebut maka sebelumnya dilakukan pengujian hipotesis. Hipotesis yang digunakan adalah sebagai berikut:

$\mathrm{H}_{0}=$ religiusitas dan rasionalitas secara parsial tidak mempunyai pengaruh signifikan terhadap pilihan nasabah pada Bank Syariah di Aceh Tengah.

$\mathrm{H}_{1}=$ religiusitas dan rasionalitas secara parsial mempunyai pengaruh signifikan terhadap pilihan nasabah pada Bank Syariah di Aceh Tengah.

Dari perhitungan Regresi dengan bantuan aplikasi SPSS 16, maka didapatkan hasil sebagai berikut:

Tabel 4.3

Hasil Perhitungan Regresi

Coefficientsa

\begin{tabular}{|c|c|c|c|c|c|}
\hline \multirow[b]{2}{*}{ Model } & \multicolumn{2}{|c|}{$\begin{array}{l}\text { Unstandardized } \\
\text { Coefficients }\end{array}$} & \multirow{2}{*}{\begin{tabular}{|l}
$\begin{array}{l}\text { Standardized } \\
\text { Coefficients }\end{array}$ \\
Beta
\end{tabular}} & \multirow[b]{2}{*}{$\mathrm{t}$} & \multirow[b]{2}{*}{ Sig. } \\
\hline & B & Std. Error & & & \\
\hline 1 (Constant) & -5.157 & 3.528 & & -1.462 & .150 \\
\hline $\mathrm{X} 1$ & .167 & .044 & .459 & 3.797 & .000 \\
\hline$X 2$ & .409 & .140 & .352 & 2.917 & .005 \\
\hline
\end{tabular}

a. Dependent Variable:

Berdasarkan hasil uji $\mathrm{t}$ pada tabel dapat diketahui bahwa variabel religiusitas berpengaruh signifikan terhadap pilihan nasabah, selanjutnya variabel rasionalitas ekonomi juga berpengaruh secara signifikan terhadap pilihan nasabah.

Berikut ini adalah hasil pengujian secara parsial yang meliputi religiusitas dan rasionalitas ekonomi terhadap pilihan nasabah pada Bank Syariah di Aceh Tengah:

1. Pengaruh Religiusitas terhadap Pilihan Nasabah 
Pengujian secara parsial antara variabel religiusitas dengan variabel pilihan menunjukkan angka signifikansi sebesar $0 \%$. Karena nilai signifikansi lebih kecil dari 5\%, maka $\mathrm{H}_{1}$ diterima, dan dapat disimpulkan bahwa religiusitas berpengaruh secara signifikan terhadap pilihan nasabah bank syariah.

2. Pengaruh Rasionalitas Ekonomi terhadap Pilihan Nasabah

Pengujian secara parsial antara variabel rasionalitas dengan pilihan menunjukkan angka signifikansi 5\%. Karena nilai signifikansi sama yaitu $5 \%$ maka $\mathrm{H}_{1}$ diterima, dan dapat disimpulkan bahwa rasionalitas ekonomi berpengaruh secara signifikan terhadap pilihan nasabah bank syariah.

\section{SIMPULAN DAN SARAN}

Berdasarkan uji f yang sudah dilakukan maka dapat disimpulkan bahwa variabel religiusitas dan rasionalitas ekonomi secara bersama - sama berpengaruh terhadap pilihan nasabah pada bank syariah di kabupaten Aceh Tengah. Berdasarkan uji $\mathrm{t}$ yang sudah dilakukan dapat diketahui bahwa secara partial baik variabel religiusitas maupun variabel rasionalitas ekonomi berpengaruh terhadap pilihan nasabah pada bank syariah di kabupaten Aceh Tengah. Artinya religiusitas dan rasionalitas ekonomi menjadi faktor determinan dalam memilih bank syariah.

Adapun saran yang dapat diberikan adalah dengan adanya pengaruh yang signifikan pada variabel religiusitas dan rasionalitas ekonomi terhadap pilihan nasabah bank syariah di Aceh Tengah, maka punya peluang yang besar dalam mengembangkan sektor industri keuangan berbasis syariah.

\section{DAFTAR PUSTAKA}

Adiwarman A. Karim. (2007). Ekonomi Mikro Islami Jakarta: PT. RajaGrafindo Persada

Alfi Muflikhah Lestari. (2015) “Pengaruh Religiusitas, Produk Bank, Kepercayaan, Pengetahuan, Dan Pelayanan Terhadap Preferensi Menabung Pada Perbankan Syariah (Studi Kasus Pada Mahasiswa Fakultas Ekonomi Dan Bisnis Universitas Brawijaya Malang)" Skripsi, Jurusan Ilmu Ekonomi Fakultas Ekonomi dan Bisnis Universitas 
Brawijaya

Ancok, D., \& Suroso, F. N. (1994). Psikologi islami solusi islam atas problemproblem psikologi. Yogyakarta: Pustaka Pelajar,1994

Atik Masruroh. (2015). “Analisis Pengaruh Tingkat Religiusitas dan Disposible Income terhadap Minat Menabung Mahasiswa di Perbankan Syariah (Studi Kasus Mahasiswa STAIN Salatiga)"Skripsi, STAIN Salatiga

Bernard Raho, SVD. (2007). Teori Sosiologi Modern, (Jakarta: Prestasi Pustakaraya

Bitha Mikkelsen. (1995). Methods for Development Work and Research: A Guide for Practitioners, translated by Matheos Nalle, $3^{\text {th }}$ Edition, Jakarta: Kencana

D. Muijs. (2004). Doing Quantitative Research in Educational with SPSS London: Sage Publications, 2004

Desy Fatmawati. (2015). "Pengaruh Pendapatan, Religiusitas, Dan Informasi Terhadap Intensi Menabung Di Bank Syariah Pada Kalangan Santri Mahasiswa Pp. Wahid Hasyim Di Sleman", Skripsi, Yogyakarta: Universitas Negeri Yogyakarta

Eko Suprayitno. (2008). Ekonomi Mikro Perspektif Islam. Malang: UIN-Malang Press

Faisal Indra Setiawan dan Ananda Sabil Hussein. (2016) “Pengaruh Persepsi Religiusitas Terhadap Loyalitas Nasabah Bank Muamalat Kota Cirebon dengan Kepuasan Nasabah Sebagai Variabel Intervening", Jurnal Ilmiah Mahasiswa Fakultas Ekonomi dan Bisnis Universitas Brawijaya.

Glock, C. Y., \& Stark, R., Religion and society in tension, (San Francisco: Rand McNally, 1970)

Gregor Polancik. (2009). Empirical Research Method Poster, Jakarta http://www.academia.edu/4370515/LEMBAGA_PERBANKAN_INDONESI A

J. H. Mc Millan \&S. Schumacher. (2006). Research in Education: Evidence-Based Inquiry

James F. Engel. (1968). Consumer Behavior Illinois: The Dryden Press, Dikutip dari buku A. A. Anwar Prabu Mangkunegara. (2002) Perilaku Konsumen. Bandung: Refika Aditama 
John W. Creswell. (2003). Research Design: Qualitative, Quantitative, and Mixed Methods Approach, 2rd edition London: Sage Publications

John Wright, The Ethics of Economic Rationalism (Sydney: University of New South Wales Press, Ltd), 2003

Kotler dikutip dalam buku Bimo Walgito. (2001). Pengantar Psikologi Umum Yogyakarta: Andi Ofset

Leon G. Schiffman dan Leslie Lazar Kanuk, Perilaku Konsumen. Terjemahan,(Jakarta: PT, Macan Jaya Cemerlang), 2008.

Monzer Kahf, A contribution to the Theory of consumer Behaviour in an Islamic Society dalam Khursyid Ahmad (ed), Studies in Islamic Economics, (Leicester: The Islamic Foundation, 1981), 22-23.

Monzer Kahf. (1995). Ekonomi Islam: Telaah Analitik terhadap Fungsi Sistem Ekonomi Islam, Cetakan I, Yogyakarta: Pustaka Pelajar

Muhammad Muflih. (2006). Perilaku Konsumen Dalam Perspektif Ilmu Ekonomi Islam, Jakarta: PT. RajaGrafindo Persada

Nikmah Zahrotun. (2013). "Pengaruh dimensi religiusitas masyarakat santri desa Kajen kecamatan Margoyoso kabupaten Pati terhadap minat menabung (studi kasus pada BPRS Artha Mas Abadi)", Skripsi, IAIN Wali Songo

nurul_q.staff.gunadarma.ac.id/Downloads/files/.../bab1-sikap-1.pdf akses 10 November 2010).

Roger LeRoy Miller. (2007). Economics Today $7^{\text {th }}$ (New York: Harper Collins Publishers, 2001), 6, dikutip dalam Adiwarman A. Karim, Ekonomi Mikro Islami. Jakarta: PT. RajaGrafindo Persada

Roscoe. 1982. Research Method for Business

S. Lichtenstein \& P. Slovic. (2006). The construction of preference. New York: Cambridge University Press

S. Sarantakos, Social Research (Melbourne: MacMillan, 1998), 299.

S.J. Kraus. (1995). Attitudes and prediction of behavior: a meta-analysis of the empirical literature." Personality and Social Psychology Bulletin, Januari $1995,21,58-75$.

Said Sa'ad Marthon. (2007). Ekonomi Islam; Di Tengah Krisis Ekonomi Global, Luthfi Yansyah (ed). Jakarta: Zikrul Hikmah.

Sambas Ali Muhidin dan Maman Abdurrahman. (2009). Analisis Korelasi, Regresi, dan Jalur dalam Penelitian. Bandung: CV. Pustaka Setia, Cetakan Pertama

Sari, L. M., (2013). Tingkat religiusitas dengan kecemasan menghadapi menopause, 
Jurnal Online Psikologi, Vol. 01, 1-11.

Siswanto. (2007). Kesehatan Mental: Konsep, Cakupan dan Perkembangannya. Yogyakarta: ANDI

Sri Utami Rahayuningsih, "Psikologi Umum 2"

Sugiyono. (2009). Statistika untuk Penelitian. Bandung: CV. Alfabeta

Suharsimin Arikunto. (1998). Prosedur Penelitian; Suatu Pendekatan Praktek. Jakarta: PT. Rineka Cipta.

T. K. Crowl. (1996). Fundamentals of Educational Research, 2nd Edition New York: McGraw - Hill

J. H. Mc Millan \&S. Schumacher. (2006). Research in Education: Evidence-Based Inquiry. New York: Pearson Education, Inc

Toni Wijaya. (2009). Analisi Data Penelitian Menggunakan SPSS Yogyakarta: Penerbit Universitas Atma Jaya

Uma Sekaran. (1992). Research Method for Business: A Skill Building Approach, $2^{\text {nd }}$ Edition, New York 